\title{
Long-Term Delivery of an Anti-SIV Monoclonal Antibody With AAV
}

\author{
José M. Martinez-Navio ${ }^{1 \dagger}$, Sebastian P. Fuchs ${ }^{1 \dagger}$, Desiree E. Mendes ${ }^{1}$, Eva G. Rakasz ${ }^{2}$, \\ Guangping $\mathrm{Gao}^{3}$, Jeffrey D. Lifson ${ }^{4}$ and Ronald C. Desrosiers ${ }^{1 *}$ \\ ${ }^{1}$ Department of Pathology, Miller School of Medicine, University of Miami, Miami, FL, United States, ${ }^{2}$ Wisconsin National \\ Primate Research Center, University of Wisconsin, Madison, WI, United States, ${ }^{3}$ Gene Therapy Center, University of \\ Massachusetts Medical School, Worcester, MA, United States, ${ }^{4}$ AIDS and Cancer Virus Program, Frederick National \\ Laboratory for Cancer Research, Frederick, MD, United States
}

Long-term delivery of anti-HIV monoclonal antibodies using adeno-associated virus (AAV) holds promise for the prevention and treatment of HIV infection. We previously reported that after receiving a single administration of AAV vector coding for anti-SIV antibody $5 \mathrm{~L} 7$, monkey 84-05 achieved high levels of AAV-delivered $5 \mathrm{~L} 7$ IgG1 in vivo which conferred

OPEN ACCESS

Edited by:

Alberto Bosque,

George Washington University,

United States

Reviewed by:

Ann Jones Hessell,

Oregon Health and Science University,

United States

Lucio Gama,

Johns Hopkins Medicine,

United States

*Correspondence:

Ronald C. Desrosiers

r.desrosiers@med.miami.edu

tThese authors have contributed equally to this work and share first authorship

Specialty section:

This article was submitted to Vaccines and Molecular Therapeutics, a section of the journal

Frontiers in Immunology

Received: 06 January 2020

Accepted: 27 February 2020

Published: 17 March 2020

Citation:

Martinez-Navio JM, Fuchs SP, Mendes DE, Rakasz EG, Gao G, Lifson JD and Desrosiers RC (2020) Long-Term Delivery of an Anti-SIV Monoclonal Antibody With AAV. Front. Immunol. 11:449. doi: 10.3389/fimmu.2020.00449 sterile protection against six successive, escalating dose, intravenous challenges with highly infectious, highly pathogenic SIVmac239, including a final challenge with 10 animal infectious doses (1). Here we report that monkey 84-05 has successfully maintained $240-350 \mu \mathrm{g} / \mathrm{ml}$ of anti-SIV antibody $5 \mathrm{~L} 7$ for over 6 years. Approximately $2 \%$ of the circulating IgG in this monkey is this one monoclonal antibody. This monkey generated little or no anti-drug antibodies (ADA) to the AAV-delivered antibody for the duration of the study. Due to the nature of the high-dose challenge used and in order to rule out a potential low-level infection not detected by regular viral loads, we have used ultrasensitive techniques to detect cell-associated viral DNA and RNA in PBMCs from this animal. In addition, we have tested serum from 84-05 by ELISA against overlapping peptides spanning the whole envelope sequence for SIVmac239 (PepScan) and against recombinant p27 and gp41 proteins. No reactivity has been detected in the ELISAs indicating the absence of naturally arising anti-SIV antibodies; moreover, the ultrasensitive cell-associated viral tests yielded no positive reaction. We conclude that macaque 84-05 was effectively protected and remained uninfected. Our data show that durable, continuous antibody expression can be achieved after one single administration of AAV and support the potential for lifelong protection against HIV from a single vector administration.

Keywords: gene therapy, AAV vector, long-term expression, broadly neutralizing antibodies, HIV/SIV cure, immunotherapy, prophylaxis, rhesus monkeys

\section{INTRODUCTION}

Gene therapy has come of age. Almost 50 years after its inception, gene therapy is now considered a promising treatment option for several human diseases including cancer, genetic disorders and infectious disease (2). Gene therapies can work by several mechanisms: replacing defective genes with healthy ones, adding new genes to help the body fight or treat disease, or deactivating problematic genes (3). Importantly, for any of these gene therapy approaches, achieving long-term delivery of the transgene remains a key, infrequently realized goal. Recombinant adeno-associated 
virus (AAV) vectors have been widely used for such gene delivery applications because of their safety and cost-efficiency: a single injection can result in long-term expression of the transgene product (4). Also, recombinant AAV is ideal as a delivery vehicle in some additional respects: the only protein expressed from it comes from the inserted transgene; it can effectively transduce terminally differentiated non-dividing cells; and it shows little or no integration into host genome sequences (5-10).

One potentially important application of the AAV system is the delivery of broadly neutralizing antibodies as a gene therapy approach against HIV $(1,11-14)$. For that purpose, recombinant AAVs encoding neutralizing antibodies are inoculated into the host and the antibody or antibodies of interest will then be directly expressed from the transduced cells. Thus, the immune system is bypassed in the sense that no immune response to an immunogen or vaccine is needed; the desired final products (broadly neutralizing antibodies) are delivered directly to the host. This approach against HIV has been made realistically possible in recent years thanks to the isolation and characterization of a remarkable collection of potent, broadlyneutralizing, monoclonal antibodies from select individuals (1517). These antibodies have been extensively characterized in the laboratory and some have moved to clinical trials, where they have shown activity (18-22). They have the potential to prevent infection and also serve as a therapeutic approach complementing or even substituting antiretroviral drugs (11, $14,18,20-25)$. Importantly, the use of AAV voids the need for repeated administrations of purified antibody to maintain therapeutic levels in circulation. Due to its simplicity and ease of deployment, the approach is ideal for global use (26).

One main problem has been encountered in the applicability of this approach. Host antibodies generated against the delivered antibody (generally known as anti-drug antibodies or ADAs) can reduce its functionality and concentration thus drastically reducing its effectiveness $(1,11,24,27-32)$. The large repertoire of endogenously generated antibodies present in any individual has gone through a complex checks and balances system to be allowed into circulation (33). The antibodies being made in one individual are different from the antibodies being made in another individual (34). In addition, the potent broadlyneutralizing anti-HIV antibodies that one would want to use for these applications are typically highly evolved over a prolonged period of time. Due to years of affinity maturation, they exhibit unusually high levels of somatic hypermutation in the variable domains and many have accumulated unusual structural features $(35,36)$ which are generally required for potent neutralization and breadth (37). This high level of mutation likely enhances the immunogenicity of these antibodies when delivered to a host other than the one in which those particular sequences originated. Interestingly, when characterizing the humoral responses to the AAV-delivered antibodies we and others have found that the variable regions were predominantly or exclusively targeted $(1,11,28,30)$. We have also reported a highly significant correlation of the magnitude of the host anti-antibody response with the distance from germline of the AAV-delivered antibody: the more mutated, the more immunogenic (28). ADAs are in fact a common problem with many gene therapy approaches
$(38,39)$. However, if the hurdle of the ADAs can be overcome, the promise of the AAV-delivery of antibodies against HIV could be realized (12). Here, we report that monkey $84-05$ has maintained $240-350 \mu \mathrm{g} / \mathrm{ml}$ of anti-SIV antibody 5L7 for over 6 years in the absence of detectable ADAs. Our data show that durable, continuous antibody expression can be achieved after a single administration of AAV and support the potential for lifelong protection against HIV from a single vector administration.

\section{MATERIALS AND METHODS}

\section{Macaque 84-05}

The animal used in this study is a Mamu $B^{*} 08$-neg $B^{*} 17$ neg female Indian-origin rhesus macaque (Macaca mulatta), originally housed at the New England Primate Research Center in a biosafety level 3 animal containment facility in accordance with the standards of the Association for Assessment and Accreditation of Laboratory Animal Care and the Harvard Medical School Animal Care and Use Committee. Research was conducted according to the principles described in the Guide for the Care and Use of Laboratory Animals and was approved by the Harvard Medical School Animal Care and Use Committee (40). Macaque 84-05 tested negative for the presence of antibodies to HIV and AAV1 capsid prior to AAV administration. At the time this manuscript was written, the monkey was 14 years old and weighted $6.4 \mathrm{~kg}$. She was administered AAV encoding for 5L7 antibody when she was 7 years old and weighted $5.5 \mathrm{~kg}$ (1). At week 108 (about 2 years) post-AAV administration, the monkey was transferred to and subsequently housed at the Wisconsin National Primate Research Center and cared for in accordance with the guidelines of the Weatherall Report under a protocol approved by the University of Wisconsin Graduate School Animal Care and Use Committee.

\section{Recombinant AAV}

Coding sequences were designed in silico, codon-optimized and gene-synthesized (GenScript). 5L7 immunoadhesin sequences (11) served as a template and full-length antibodies were constructed by adding $\mathrm{CH} 1$ domain and $\mathrm{CL}$ domain of rhesus IgG to the already known immunoadhesin sequences. 5L7 sequences originate from recombinant anti-SIV Fab sequences (347-23h) derived from the bone marrow of SIV-infected rhesus monkeys (41). The rhesus IgG1 sequence used is based on accession no. AAF14058 and AAQ57555. Rhesus kappa light chain was designed using the constant light domain sequence from AAD02577. Synthesized fragments were then cloned into the NotI site of our AAV vector plasmids $(1,42)$. Production of recombinant AAVs was conducted as described previously (43). In short, HEK-293 cells were transfected with a select AAV vector plasmid and two helper plasmids to allow generation of infectious AAV particles. After harvesting transfected cells and cell culture supernatant, AAV was purified by three sequential $\mathrm{CsCl}$ centrifugation steps. Vector genome number was assessed by Real-Time PCR, and the purity of the preparation was verified by electron microscopy and silver-stained SDS-PAGE. The AAV genomes were encapsidated with the AAV1 serotype. 
Monkey 84-05 received recombinant AAV1 encoding the antiSIV antibody 5L7, using a total dose of $1.6 \times 10^{13}$ particles $(2.9$ $\times 10^{12}$ AAV vector genomes per kilogram of body weight). AAV administration was conducted by a one-time inoculation of four deep intramuscular injections (two separate $0.5 \mathrm{ml}$ injections into both quadriceps).

\section{Recombinant 5L7 Antibody}

5L7 recognizes gp120 and gp140 forms of the SIVmac239 envelope glycoprotein (28) and binds conformational epitopes involving the V3-V4 region (41). HEK-293T cells were expanded and then transfected with recombinant AAV vector plasmid coding for 5L7 antibody. Cells were washed after $4 \mathrm{~h}$ with pre-warmed PBS and then transferred to serum-free medium (Invitrogen). Afterwards, the antibody-containing medium was harvested, precleared by centrifugation, and filtered through a $0.22 \mu \mathrm{m}$-pore-size membrane. Then, IgG was affinity-purified using protein A Sepharose 4 Fast Flow (GE Healthcare), concentrated and desalted, followed by protein quantification with a Nanodrop UV spectrometer (Thermo Fisher Scientific). Antibody purity was confirmed by sodium dodecyl sulfatepolyacrylamide gel electrophoresis (SDS-PAGE) and subsequent Coomassie blue staining (Thermo Fisher Scientific).

\section{In vivo 5L7 Antibody Quantification and Anti-Drug Antibody (ADA) Responses}

AAV-delivered 5L7 antibody was quantitated by standard ELISA using plate bound SIVmac239 gp140 (Immune Tech) to capture the antibody from pre-diluted serum samples and then HRPconjugated secondary anti-rhesus IgG (Southern Biotech) as the detection method. Absorbance at $450 \mathrm{~nm}$ was compared to a serial dilution of purified 5L7 produced in HEK 293T cells, and the amount of antibody in serum was interpolated based on the standard curve. To measure host humoral responses to the AAVdelivered 5L7 antibody, purified recombinant 5L7 was used to coat plates. Then, serum samples from monkey $84-05$ were tested at a 1:20 dilution and ADA responses were detected by means of an anti-lambda HRP-conjugated secondary antibody (Southern Biotech) in a regular ELISA (28). This secondary did not crossreact with 5L7 coated on the plates since 5L7 bears a kappa light chain. This allowed us to readily detect those anti-antibodies with a lambda light chain, which have been reported to reflect humoral responses in our previous studies $(1,28)$. Levels of AAV-delivered 5L7, and the corresponding ADAs, were measured for a total of 340 weeks.

\section{PepScan}

PepScan or ELISA against a panel of 218 peptides overlapping the entire SIVmac239 envelope protein was used to detect antibody responses to the viral spike. Fifteen-mer-length peptides, each successive peptide overlapped by 11 amino acids, were obtained from the NIH AIDS Research and Reference Reagent Program. Peptides were properly resuspended and used to coat ELISA plates at $40 \mu \mathrm{g} / \mathrm{ml}$ in phosphate-buffered saline (PBS). Plates were then washed, blocked and incubated for $1 \mathrm{~h}$ at $37^{\circ} \mathrm{C}$ with a 1:20 dilution of the corresponding monkey sera or 5L7 antibody diluted to $2 \mu \mathrm{g} / \mathrm{ml}$. Binding antibodies were detected with an HRP-conjugated goat anti-human IgG antibody (SouthernBiotech) diluted 1:1,000 in 5\% non-fat powdered milk in PBS and developed with soluble tetramethylbenzidine (TMB) reagent (Calbiochem, Gibbstown, NJ). The reaction was stopped by the addition of $50 \mu \mathrm{l}$ of acidic stop solution (SouthernBiotech, Birmingham, AL), and the optical density at $450 \mathrm{~nm}$ was measured using a Wallac Victor plate reader (Perkin-Elmer, Waltham, MA).

\section{Antibody Responses to p27 and gp41}

Antibody responses against p27 and gp41 were quantitated by regular ELISA using SIVmac239 p27 purified recombinant protein (Catalog\# 13446; obtained through the NIH AIDS Reagent Program, Division of AIDS, NIAID, NIH) and recombinant SIV gp41 (Catalog\# 5019; ImmunoDX) to coat plates at $10 \mu \mathrm{g} / \mathrm{ml}$ in PBS. Plates were then washed, blocked and incubated for $1 \mathrm{~h}$ at $37^{\circ} \mathrm{C}$ with a $1: 20$ dilution of the corresponding monkey sera or 5L7 antibody diluted to $2 \mu \mathrm{g} / \mathrm{ml}$. Antibodies binding the p27 antigen or the gp41 were detected with a goat anti-monkey secondary antibody (Catalog\# 2015-05, Santa Cruz) and developed with TMB High Sensitivity Substrate Solution (Catalog\# 421501, Biolegend). The reaction was stopped by the addition of $50 \mu \mathrm{l}$ of acidic stop solution (SouthernBiotech, Birmingham, AL), and the optical density at $450 \mathrm{~nm}$ was measured using a Wallac Victor plate reader (Perkin-Elmer, Waltham, MA).

\section{Viral Load Monitoring}

Plasma SIV RNA was measured using a gag-targeted quantitative real-time/digital PCR method with 6 replicate reactions analyzed per extracted sample for an assay threshold of 30 SIV RNA copies/ml (44). Cell-associated SIV RNA and DNA were measured by quantitative hybrid real-time/digital RT-PCR and PCR assays $(45,46)$.

\section{RESULTS}

\section{Over 6 Years of Continuous Antibody Expression in vivo}

Monkey 84-05 received a single administration of AAV on September 6th, 2012. As we reported at that time (1), starting at week 44 post-AAV inoculation and then every 3 weeks, this animal was repeatedly challenged with highly pathogenic, highly infectious SIVmac239 for a total of six intravenous administrations (see schematics in Figure 1A). The first four challenges were performed with 1 animal infectious dose (AID), followed by challenge with 2 AID and then a final 10 AID challenge. Viral load measurements in plasma from 84-05 were negative $(<30$ copies $/ \mathrm{ml})$, indicating the animal successfully resisted all six challenges (1). The antibody levels achieved remarkable values of $\sim 270 \mu \mathrm{g} / \mathrm{ml}$ (1). We now report long-term follow-up on levels of 5L7 antibody and the corresponding ADAs in circulation. As shown in Figure 1B, macaque 84-05 has successfully maintained $240-350 \mu \mathrm{g} / \mathrm{ml}$ of anti-SIV antibody 5L7 for over 340 weeks ( $>6$ years). Moreover, this animal has 


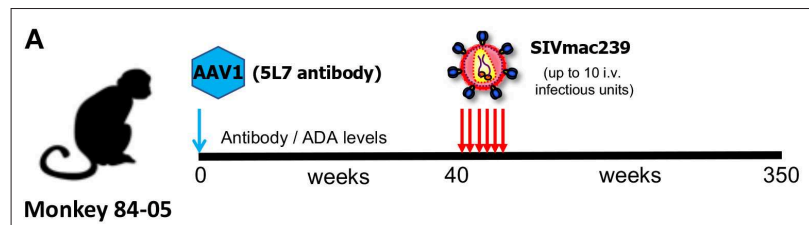

B

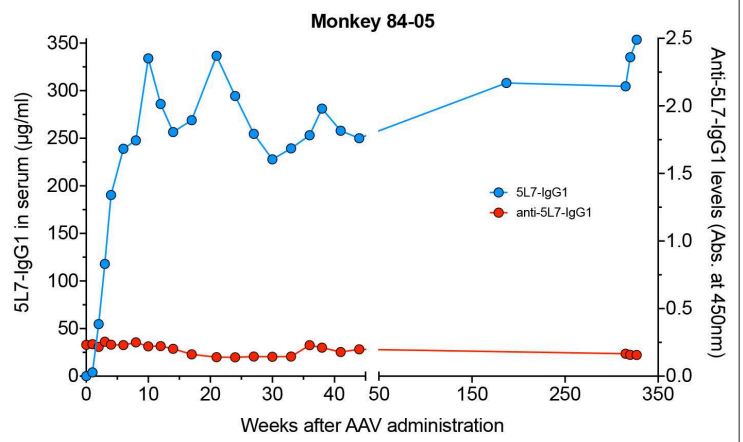

FIGURE 1 | $5 \mathrm{~L} 7$ antibody levels and the corresponding anti-antibodies (ADAs) in serum following AAV administration. (A) Schematic of the experiment in which rhesus monkey 84-05 received intramuscular administration of AAV1 coding for antibody $5 \mathrm{~L} 7$ and was subsequently challenged with SIVmac239 (six times: 4 times with a 1 animal infectious doses followed by a 2x dose challenge and a final 10x dose challenge). (B) $5 \mathrm{~L} 7$ antibody levels (blue; plotted on left axis) and anti-5L7 antibody levels (red; plotted on right axis) in serum from monkey $84-05$, quantified by ELISA.

shown little or no ADA responses to the AAV-delivered 5L7 antibody (Figure 1B).

\section{Negative Envelope PepScan}

Due to the nature of the high-dose challenge employed, and the high levels of anti-envelope reactivity found in serum of this animal, one could speculate about a potential low-level infection not detected by regular viral load measurements, which could lead to development of endogenous anti-Env responses, resulting in an overestimation of the concentration of 5L7 antibody in the anti-SIVmac239 gp140 ELISA employed (see Materials and Methods). In order to rule out this potential scenario, we tested serum from $84-05$ by PepScan (ELISA against overlapping peptides spanning the whole envelope sequence for SIVmac239) $(47,48)$. One of the most sensitive measures of infection is seroconversion. Established immunodominant regions of the envelope, i.e., the variable loops $\mathrm{V} 1-\mathrm{V} 2$ and $\mathrm{V} 3$, the C terminus of gp120, some peptides in the ectodomain of gp41, and the highly immunogenic region (HIR) at the beginning of the cytoplasmic tail of gp41(47-49) are the regions frequently targeted by antibodies. As shown in Figure 2A, the serum from this animal did not detectably react to any of the peptides in the SIVmac239 envelope PepScan. Importantly, and as expected, recombinant purified antibody $5 \mathrm{~L} 7$ (which is known to bind a conformational epitope involving the V3-V4 region of the envelope $(11,41)$ and should therefore not bind the linear epitopes present in the PepScan), did not detectably bind any of the tested peptides (Figure 2B). Conversely, when positive control serum from a SIV-infected macaque (r10028) was tested

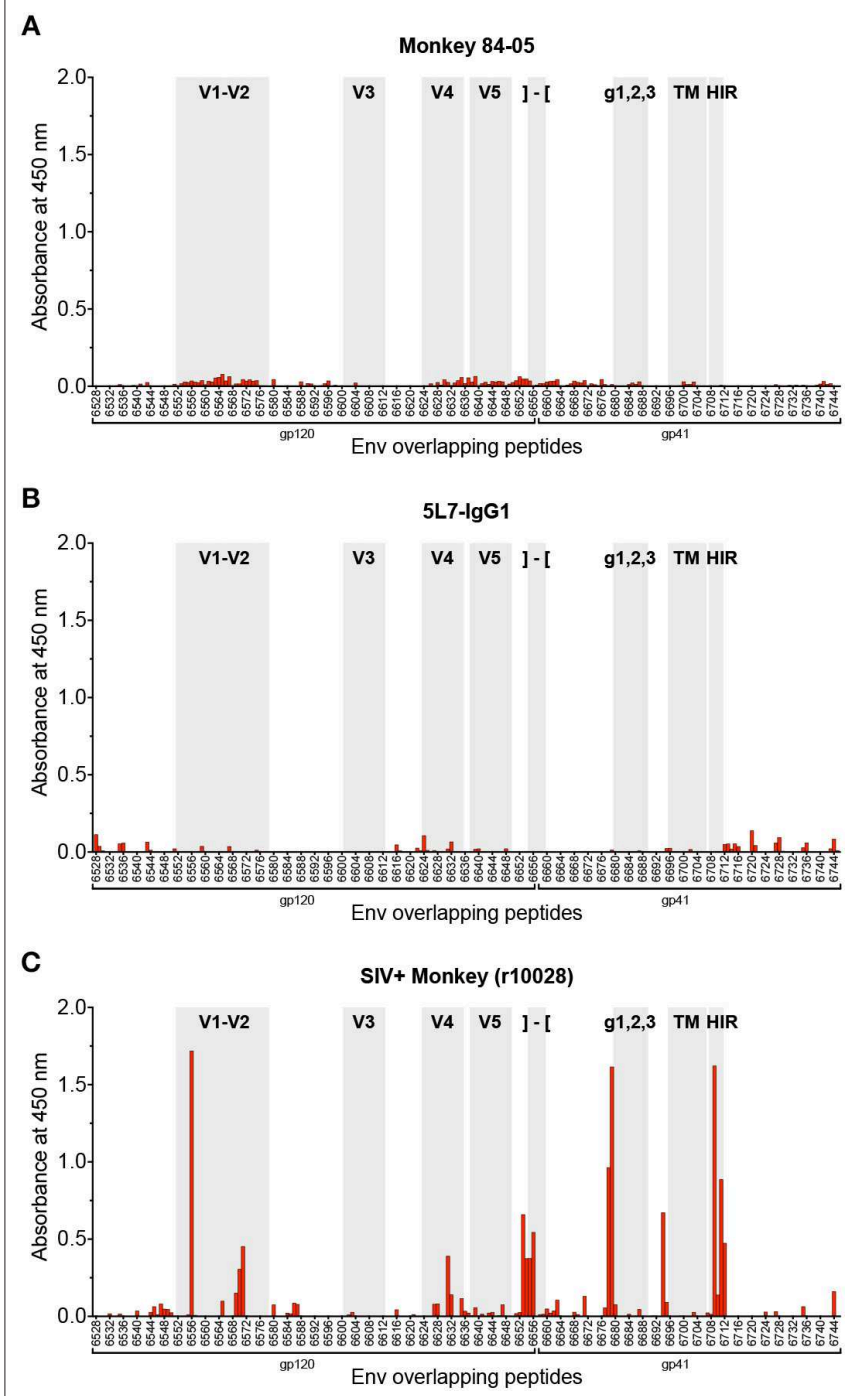

FIGURE 2 | Analysis of antibody responses by PepScan. PepScan (ELISA against overlapping peptides) spanning the whole envelope sequence for SIVmac239, performed with (A) serum from 84-05 (week 328 post-AAV) at a 1:20 dilution; (B) recombinant purified $5 \mathrm{~L} 7$ antibody at a concentration of $2 \mu \mathrm{g} / \mathrm{ml}$; and (C) serum from a rhesus monkey experimentally infected with SIVmac239 (week 12 post-SIV infection) at a 1:20 dilution. Note: regions of interest are shadowed in gray and indicated as follows: variable regions 1-2, 3, 4 , and 5 are labeled $V_{1}-V_{2}, V_{3}, V_{4}$, and $V_{5}$, respectively; the cleavage site and beginning of gp41 are represented by brackets; g123 indicates the location of the $\mathrm{N}$-linked carbohydrate sites found in gp41; TM is the transmembrane domain of gp41; and HIR stands for highly immunogenic region. Data from SIV+ monkey in panel $\mathbf{( C )}$ is representative of many such SIV+ monkeys tested previously $(47,48)$.

on a PepScan in the same conditions, strong reactivity was shown to the immunodominant regions cited above (Figure 2C).

\section{No Detectable Antibody Responses to p27 or gp41 by ELISA}

With the high levels of 5L7 antibody consistently found in serum of $84-05$, meaning high reactivity to gp120, assessing 

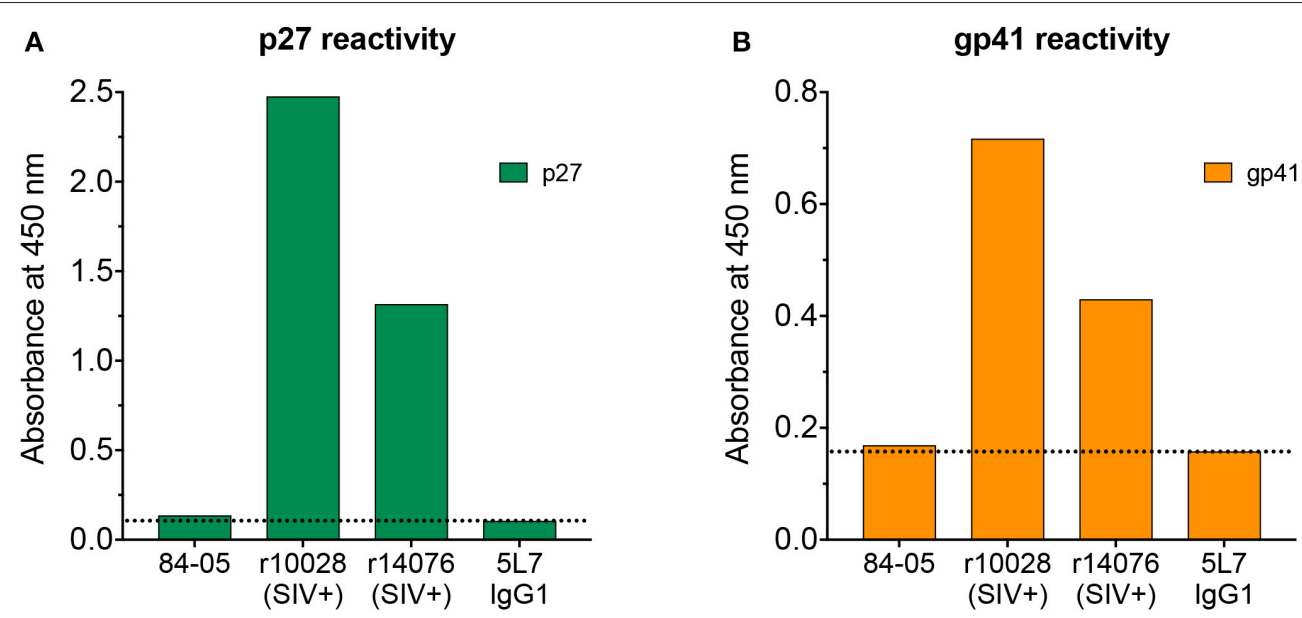

FIGURE 3 | Analysis of antibody responses to p27 and gp41. Serum from 84-05 (week 328 post-AAV) at a 1:20 dilution was tested by ELISA against recombinant purified proteins p27 (A) gp41 and (B) sera from two rhesus monkeys experimentally infected with SIVmac239 (week 12 post-SIV infection) at a 1:20 dilution were used as positive controls, and recombinant purified $5 \mathrm{~L} 7$ as a negative.

a potential low-level infection can be complicated since that serum would definitely yield a positive result when tested against whole virus or recombinant gp120 by ELISA, the benchmark assays. An alternate method to test potential seroconversion is by measuring ELISA reactivity to p27 and gp41 recombinant proteins. Antibodies to both p27 and gp41 are readily detectable shortly after SIV infection and importantly, the 5L7 antibody present in the serum would not react to these proteins. Tests of serum from 84-05 (week 328 post-AAV) did not reveal any reactivity to p27 (Figure $3 \mathrm{~A}$ ), while positive control sera from two rhesus macaques experimentally infected with SIVmac239 for 12 weeks (r10028 and r14076) showed high reactivity under the same conditions. Similarly, serum from 84-05 did not detectably react against gp41, but sera from the two SIV-positive monkeys did (Figure 3B). Purified 5L7 antibody tested in parallel did not significantly bind to either p27 or gp41 (Figure 3).

\section{Absence of Cell-Associated Viral DNA or RNA}

To further rule out a potential low-level infection that could not be detected by the aforementioned ELISA-based tests, we used ultrasensitive techniques to detect cell-associated viral DNA and RNA in PBMCs from 84-05. We did not detect SIV gag RNA or DNA in the analysis of a combined total of $1.17 \times 10^{8}$ cell equivalents obtained over a 2-week period (week 340 and week 342; Table 1) with a nominal sensitivity of 1 copy per reaction.

\section{DISCUSSION}

Here we describe continuous, prolonged, high level delivery of an antibody to a rhesus monkey using AAV vector over 6 years of longitudinal measurements. Approximately 2\% of the IgG in monkey $84-05$ is derived from the vector that we inoculated more than 6 years previous. This result is consistent with the belief that muscle cells essentially do not turn over
TABLE 1 | Ultrasensitive detection of cell-associated viral DNA and RNA in PBMCs.

\begin{tabular}{|c|c|c|}
\hline & Week $340^{a}$ & Week $342^{b}$ \\
\hline Cell associated viral DNA & $<1$ DNA copies $/ 10^{6}$ cells & $<1$ DNA copies $/ 10^{6}$ cells \\
\hline Cell associated viral RNA & $<1$ RNA copies $/ 10^{6}$ cells & $<1$ RNA copies $/ 10^{6}$ cells \\
\hline
\end{tabular}

(50) and thus represent a potentially long term stable source of AAV-delivered antibody. It seems likely that monkey 8405 will continue to produce similar levels of this antibody for the rest of its life. Importantly, this animal withstood six successive challenges with SIVmac239, including a final challenge with 10 animal infectious doses (1). By different means we show here that monkey 84-05 was effectively protected and remained uninfected: these include testing seroconversion in three different ways and the use of ultrasensitive techniques to detect cell-associated viral DNA and RNA. Due to the difficulties associated with proving curative and/or protective interventions (51), additional tests were considered such as in vivo CD8+ T-cell depletion and attempts at adoptive transfer of infection to naïve rhesus macaques. However, we did not want to put this precious monkey at any risk with the CD8 depletion; and, surprisingly, adoptive transfer may not be as sensitive as one would think (14).

The absence of an ADA response is almost certainly a key factor in the continuous production of the transgene product in monkey 84-05. Other examples of AAV delivery of protein to monkeys over a prolonged period have been documented in the reports of Rivera et al. (52) and Guilbaud et al. (53). Both of these reports used periodic induction of expression of an erythropoietin identical in sequence to the monkey's own erythropoietin over 5 or more years of study. Additional examples include the persistent expression of 
dopamine-synthesizing enzymes in the putamen reported in one monkey for 15 years in a primate model of Parkinson's disease (54); the sustained expression of human $\alpha$-L-iduronidase, an important enzyme required for the lysosomal degradation of glycosaminoglycans, reported for almost 4 years after intrathecal cervical AAV9 gene delivery in four one-month-old rhesus monkeys (55); the sustained expression of alpha-1 antitrypsin for over 5 years after one AAV vector administration in alpha-1 antitrypsin deficient patients (56); and the successful expression for 3.5 years obtained in two dogs of a dystrophin gene in a canine model for human Duchenne muscular dystrophy using AAV6 and a brief course of immunosuppressants (57), or in a similar study for over 2 years in two dogs using AAV8 in the absence of immunosuppression (58). Remarkably our animal 84-05 never received any immunosuppressant. The hemophilia gene therapy arena also has good examples of long-term delivery with AAV for up to a decade of Factor IX in hemophilic humans (59) and of Factor VIII in hemophilic dogs (60). For more examples on long-term delivery with AAV of hemophilia factors, please see the following references (61-68). The long-term delivery described in our report here is significant as the first such report for very long-term delivery of an antibody, particularly given the serious difficulties that have been encountered when AAV has been used to deliver antibodies that are significantly diverged from germ line or contain unusual features $(1,14,28,30,31)$. The findings give hope that long-term delivery of therapeutic antibodies via AAV can be consistently achieved if the ADA problem can be overcome.

What may be responsible for the absence of ADAs in 8405 and the continued high level of production of the transgene product over this prolonged period? Factors that have been shown to influence whether, or not, ADAs are observed following AAV-mediated expression of a transgene product include the following: the particular sequence of the transgene product (69); whether the recipient is already making a similar or identical protein (39); the serotype of AAV used (38); and targeted delivery or targeted expression at particular sites or in particular tissues or cells (54, 70-76). AAV-delivered 5L7 antibody certainly has the potential to be immunogenic in rhesus monkeys since $50 \%$ of monkeys receiving it have had robust ADA responses (1). Might there be particular genetic determinants that restrict an ADA response to the 5L7 antibody in some monkeys but not others? Might the antibody repertoire present in an individual at any one time influence to what extent the 5L7 antibody may be recognized as foreign? Might 5L7 just be on the cusp of self/nonself recognition? These questions remain unanswered at least for the time being.

Like the Miami monkey $(14,77,78)$, monkey 84-05 stands out as a shining example of what is possible in the realm of AAV delivery of monoclonal antibodies in the fight against HIV. The Miami monkey has maintained high levels of two anti-HIV monoclonal antibodies and complete virologic suppression of SHIV infection for more than 4 years of followup without any repeated administrations and without any other antiviral therapies. It is likely that the ADA problem with AAV-delivered antibodies will need to be overcome for this approach to become a consistent reality in the context of human HIV infection. A recently-published human trial of AAV to deliver the human anti-HIV monoclonal antibody PG9 revealed readily detectable ADAs in 10 of 13 recipients in the four highest dose groups and zero measurable delivery of the PG9 antibody $(31,79)$. We feel that monkey modeling will need to play a key role in the development of successful strategies. Our group is currently focused on simple, easy-toapply strategies for creating tolerance in monkeys to AAVdelivered monoclonal antibodies. If satisfactory delivery methods are found, it becomes possible to envision long-term control of viral replication in the absence of antiretroviral treatment by delivering a combination of antibodies in people, and longlasting protection when this approach is used in a prophylactic setting. The long-term expression reported here highlights the potential of AAV-mediated antibody expression for impacting HIV-1 infections worldwide.

\section{DATA AVAILABILITY STATEMENT}

All datasets generated for this study are included in the article/supplementary material.

\section{ETHICS STATEMENT}

The animal study was reviewed and approved by The Harvard Medical School Animal Care and Use Committee and The University of Wisconsin Graduate School Animal Care and Use Committee.

\section{AUTHOR CONTRIBUTIONS}

The study was conceived and designed and the manuscript was composed by JM-N, SF, and RD. The experiments were performed by JM-N, SF, DM, ER, GG, and JL. Reagents that were used in the study were generated by JM-N, SF, DM, ER, GG, and JL. Data analysis was performed by JM-N, SF, DM, ER, GG, JL, and RD.

\section{FUNDING}

This project was supported by National Institutes of Health (NIH) grants P01 AI100263, R01 AI098446, and U19 AI095985 (to RD) and by P51 base grant RR000167 (Wisconsin National Primate Research Center) from the NIH. We also acknowledge support from the Miami Center for AIDS Research (to JM-N and to SF) at the University of Miami Miller School of Medicine funded by grant P30AI073961 from the NIH. This project has been funded in part with federal funds from the National Cancer Institute, NIH, under contracts HHSN261200800001E and 75N91019D00024 (JL).

\section{ACKNOWLEDGMENTS}

The authors thank Kimberly L. Weisgrau and Jessica Furlott for technical assistance; the Gene Therapy Core at the University of Massachusetts Medical School for excellent AAV 
vector preparation; the Wisconsin National Primate Research Center veterinary staff for professional animal care; Nancy Schultz-Darken, Wendy Newton, and Eric Alexander for animal experiment planning and conduct; and William J. Bosche, Randy
Fast, Michael Hull, Kelli Oswald, and Rebecca Shoemaker of the Quantitative Molecular Virology Core in the AIDS and Cancer Virus Program of the Frederick National Laboratory for Cancer Research for expert technical assistance with viral quantitation.

\section{REFERENCES}

1. Fuchs SP, Martinez-Navio JM, Piatak MJr, Lifson JD, Gao G, Desrosiers RC. AAV-delivered antibody mediates significant protective effects against SIVmac239 challenge in the absence of neutralizing activity. PLoS Pathog. (2015) 11:e1005090. doi: 10.1371/journal.ppat.1005090

2. Dunbar CE, High KA, Joung JK, Kohn DB, Ozawa K, Sadelain M. Gene therapy comes of age. Science. (2018) 359:eaan4672. doi: 10.1126/science.aan 4672

3. FDA. U.S. Food and Drug Administration - What is Gene Therapy? (2018). Available online at: https://www.fda.gov/vaccines-blood-biologics/cellulargene-therapy-products/what-gene-therapy

4. Hastie E, Samulski RJ. Adeno-associated virus at 50: a golden anniversary of discovery, research, and gene therapy success-a personal perspective. Hum Gene Ther. (2015) 26:257-65. doi: 10.1089/hum.2015.025

5. Goncalves MA. Adeno-associated virus: from defective virus to effective vector. Virol J. (2005) 2:43. doi: 10.1186/1743-422X-2-43

6. Daya S, Berns KI. Gene therapy using adeno-associated virus vectors. Clin Microbiol Rev. (2008) 21:583-93. doi: 10.1128/CMR.00008-08

7. McCarty DM. Self-complementary AAV vectors; advances and applications. Mol Ther. (2008) 16:1648-56. doi: 10.1038/mt.2008.171

8. Schultz BR, Chamberlain JS. Recombinant adeno-associated virus transduction and integration. Mol Ther. (2008) 16:118999. doi: 10.1038/mt.2008.103

9. Mingozzi F, High KA. Therapeutic in vivo gene transfer for genetic disease using AAV: progress and challenges. Nat Rev Genet. (2011) 12:34155. doi: $10.1038 / \mathrm{nrg} 2988$

10. Wang D, Tai PWL, Gao G. Adeno-associated virus vector as a platform for gene therapy delivery. Nat Rev Drug Discov. (2019) 18:358-78. doi: 10.1038/s41573-019-0012-9

11. Johnson PR, Schnepp BC, Zhang J, Connell MJ, Greene SM, Yuste E, et al. Vector-mediated gene transfer engenders long-lived neutralizing activity and protection against SIV infection in monkeys. Nat Med. (2009) 15:9016. doi: $10.1038 / \mathrm{nm} .1967$

12. Fuchs SP, Desrosiers RC. Promise and problems associated with the use of recombinant AAV for the delivery of anti-HIV antibodies. Mol Ther Methods Clin Dev. (2016) 3:16068. doi: 10.1038/mtm.2016.68

13. Brady JM, Baltimore D, Balazs AB. Antibody gene transfer with adenoassociated viral vectors as a method for HIV prevention. Immunol Rev. (2017) 275:324-33. doi: 10.1111/imr.12478

14. Martinez-Navio JM, Fuchs SP, Pantry SN, Lauer WA, Duggan NN, Keele BF. Deno-associated virus delivery of anti-HIV monoclonal antibodies can drive long-term virologic suppression. Immunity. (2019) 50:567-75 e5. doi: 10.1016/j.immuni.2019.02.005

15. Sok D, Burton DR. Recent progress in broadly neutralizing antibodies to HIV. Nat Immunol. (2018) 19:1179-88. doi: 10.1038/s41590-018-0 235-7

16. Dashti A, DeVico AL, Lewis GK, Sajadi MM. Broadly neutralizing antibodies against HIV: back to blood. Trends Mol Med. (2019) 25:22840. doi: 10.1016/j.molmed.2019.01.007

17. Haynes BF, Burton DR, Mascola JR. Multiple roles for HIV broadly neutralizing antibodies. Sci Transl Med. (2019) 11:eaaz2686. doi: 10.1126/scitranslmed.aaz2686

18. Caskey M, Klein F, Lorenzi JC, Seaman MS, West AP Jr, Buckley N, et al. Viraemia suppressed in HIV-1-infected humans by broadly neutralizing antibody 3BNC117. Nature. (2015) 522:487-91. doi: 10.1038/nature14411

19. Bar KJ, Sneller MC, Harrison LJ, Justement JS, Overton ET, Petrone ME, et al. Effect of HIV antibody VRC01 on viral rebound after treatment interruption. N Engl J Med. (2016) 375:2037-50. doi: 10.1056/NEJMoa1608243
20. Scheid JF, Horwitz JA, Bar-On Y, Kreider EF, Lu CL, Lorenzi JC, et al. HIV1 antibody 3BNC117 suppresses viral rebound in humans during treatment interruption. Nature. (2016) 535:556-60. doi: 10.1038/nature18929

21. Caskey M, Schoofs T, Gruell H, Settler A, Karagounis T, Kreider EF, et al. Antibody 10-1074 suppresses viremia in HIV-1-infected individuals. Nat Med. (2017) 23:185-91. doi: 10.1038/nm.4268

22. Mendoza P, Gruell H, Nogueira L, Pai JA, Butler AL, Millard K, et al. Combination therapy with anti-HIV-1 antibodies maintains viral suppression. Nature. (2018) 561:479-84. doi: 10.1038/s41586-018-0531-2

23. Balazs AB, Chen J, Hong CM, Rao DS, Yang L, Baltimore D. Antibody-based protection against HIV infection by vectored immunoprophylaxis. Nature. (2011) 481:81-4. doi: 10.1038/nature10660

24. Gardner MR, Kattenhorn LM, Kondur HR, von Schaewen M, Dorfman T, Chiang JJ, et al. AAV-expressed eCD4-Ig provides durable protection from multiple SHIV challenges. Nature. (2015) 519:87-91. doi: 10.1038/nature14264

25. Gardner MR, Fellinger $\mathrm{CH}$, Kattenhorn LM, Davis-Gardner ME, Weber JA, Alfant B. AAV-delivered eCD4-Ig protects rhesus macaques from high-dose SIVmac239 challenges. Sci. Transl. Med. (2019) 11:eaau5409. doi: 10.1126/scitranslmed.aau5409

26. Hollevoet K, Declerck PJ. State of play and clinical prospects of antibody gene transfer. J Transl Med. (2017) 15:131. doi: 10.1186/s12967-017-1234-4

27. Saunders KO, Wang L, Joyce MG, Yang ZY, Balazs AB, Cheng C, et al. Broadly neutralizing human immunodeficiency virus type 1 antibody gene transfer protects nonhuman primates from mucosal simian-human immunodeficiency virus infection. J Virol. (2015) 89:8334-45. doi: 10.1128/JVI.00908-15

28. Martinez-Navio JM, Fuchs SP, Pedreno-Lopez S, Rakasz EG, Gao G, Desrosiers RC. Host anti-antibody responses following adeno-associated virus-mediated delivery of antibodies against HIV and SIV in rhesus monkeys. Mol Ther. (2016) 24:76-86. doi: 10.1038/mt.2015.191

29. Welles HC, Jennewein MF, Mason RD, Narpala S, Wang L, Cheng $\mathrm{C}$, et al. Vectored delivery of anti-SIV envelope targeting $\mathrm{mAb}$ via AAV8 protects rhesus macaques from repeated limiting dose intrarectal swarm SIVsmE660 challenge. PLoS Pathog. (2018) 14:e1007395. doi: 10.1371/journal.ppat.1007395

30. Gardner MR, Fetzer I, Kattenhorn LM, Davis-Gardner ME, Zhou AS, Alfant B, et al. Anti-drug antibody responses impair prophylaxis mediated by AAVdelivered HIV-1 broadly neutralizing antibodies. Mol Ther. (2019) 27:65060. doi: 10.1016/j.ymthe.2019.01.004

31. Priddy FH, Lewis DJM, Gelderblom HC, Hassanin H, Streatfield C, LaBranche $\mathrm{C}$, et al. Adeno-associated virus vectored immunoprophylaxis to prevent HIV in healthy adults: a phase 1 randomised controlled trial. Lancet HIV. (2019) 6:e230-9. doi: 10.1016/S2352-3018(19)30003-7

32. van den Berg FT, Makoah NA, Ali SA, Scott TA, Mapengo RE, Mutsvunguma LZ. AAV-mediated expression of broadly neutralizing and vaccine-like antibodies targeting the HIV-1 envelope V2 region. Mol Ther Methods Clin Dev. (2019) 14:100-12. doi: 10.1016/j.omtm.2019.06.002

33. Wardemann H, Yurasov S, Schaefer A, Young JW, Meffre E, Nussenzweig MC. Predominant autoantibody production by early human B cell precursors. Science. (2003) 301:1374-7. doi: 10.1126/science.1086907

34. Wang C, Liu Y, Cavanagh MM, Le Saux S, Qi Q, Roskin KM, et al. Bcell repertoire responses to varicella-zoster vaccination in human identical twins. Proc Natl Acad Sci USA. (2015) 112:500-5. doi: 10.1073/pnas.14158 75112

35. Scheid JF, Mouquet H, Ueberheide B, Diskin R, Klein F, Oliveira TY, et al. Sequence and structural convergence of broad and potent HIV antibodies that mimic CD4 binding. Science. (2011) 333:16337. doi: $10.1126 /$ science. 1207227 
36. Klein F, Mouquet H, Dosenovic P, Scheid JF, Scharf L, Nussenzweig MC. Antibodies in HIV-1 vaccine development and therapy. Science. (2013) 341:1199-204. doi: 10.1126/science.1241144

37. Klein F, Diskin R, Scheid JF, Gaebler C, Mouquet H, Georgiev IS, et al. Somatic mutations of the immunoglobulin framework are generally required for broad and potent HIV-1 neutralization. Cell. (2013) 153:12638. doi: 10.1016/j.cell.2013.03.018

38. Mingozzi F, High KA. Immune responses to AAV vectors: overcoming barriers to successful gene therapy. Blood. (2013) 122:23-36. doi: 10.1182/blood-2013-01-306647

39. Herzog RW. Complexity of immune responses to AAV transgene products - example of factor IX. Cell Immunol. (2019) 342:103658. doi: 10.1016/j.cellimm.2017.05.006

40. National Research Council IoLAR. Commission on Life Sciences (1996). Guide for the Care and Use of Laboratory Animals. Washington, DC: The National Academies Press. doi: 10.17226/5140

41. Johnson WE, Sanford H, Schwall L, Burton DR, Parren PW, Robinson JE, et al. Assorted mutations in the envelope gene of simian immunodeficiency virus lead to loss of neutralization resistance against antibodies representing a broad spectrum of specificities. J Virol. (2003) 77:9993-10003. doi: 10.1128/JVI.77.18.9993-10003.2003

42. Fuchs SP, Martinez-Navio JM, Gao G, Desrosiers RC. Recombinant AAV vectors for enhanced expression of authentic IgG. PLoS ONE. (2016) 11:e0158009. doi: 10.1371/journal.pone.0158009

43. Mueller C, Ratner D, Zhong L, Esteves-Sena M, Gao G. Production and discovery of novel recombinant adenoassociated viral vectors. Curr Protoc Microbiol. (2012) Chapter 14:Unit14D.1. doi: 10.1002/9780471729259.mc14d01s26

44. Li H, Wang S, Kong R, Ding W, Lee FH, Parker Z, et al. Envelope residue 375 substitutions in simian-human immunodeficiency viruses enhance CD4 binding and replication in rhesus macaques. Proc Natl Acad Sci USA. (2016) 113:E3413-22. doi: 10.1073/pnas.1606636113

45. Hansen SG, Piatak M Jr, Ventura AB, Hughes CM, Gilbride RM, Ford JC, et al. Immune clearance of highly pathogenic SIV infection. Nature. (2013) 502:100-4. doi: 10.1038/nature12519

46. Hansen SG, Piatak M, Ventura AB, Hughes CM, Gilbride RM, Ford JC, et al. Addendum: immune clearance of highly pathogenic SIV infection. Nature. (2017) 547:123-4. doi: 10.1038/nature22984

47. Yuste E, Bixby J, Lifson J, Sato S, Johnson W, Desrosiers R. Glycosylation of gp41 of simian immunodeficiency virus shields epitopes that can be targets for neutralizing antibodies. J Virol. (2008) 82:12472-86. doi: 10.1128/JVI.01382-08

48. Martinez-Navio JM, Desrosiers RC. Neutralizing capacity of monoclonal antibodies that recognize peptide sequences underlying the carbohydrates on gp41 of simian immunodeficiency virus. J Virol. (2012) 86:1248493. doi: 10.1128/JVI.01959-12

49. Postler TS, Martinez-Navio JM, Yuste E, Desrosiers RC. Evidence against extracellular exposure of a highly immunogenic region in the C-terminal domain of the simian immunodeficiency virus gp41 transmembrane protein. J Virol. (2012) 86:1145-57. doi: 10.1128/JVI.06463-11

50. Spalding KL, Bhardwaj RD, Buchholz BA, Druid H, Frisen J. Retrospective birth dating of cells in humans. Cell. (2005) 122:133-43. doi: 10.1016/j.cell.2005.04.028

51. Yukl SA, Boritz E, Busch M, Bentsen C, Chun TW, Douek D, et al. Challenges in detecting HIV persistence during potentially curative interventions: a study of the berlin patient. PLoS Pathog. (2013) 9:e1003347. doi: 10.1371/journal.ppat.1003347

52. Rivera VM, Gao GP, Grant RL, Schnell MA, Zoltick PW, Rozamus LW, et al. Long-term pharmacologically regulated expression of erythropoietin in primates following AAV-mediated gene transfer. Blood. (2005) 105:142430. doi: 10.1182/blood-2004-06-2501

53. Guilbaud M, Devaux M, Couzinie C, Le Duff J, Toromanoff A, Vandamme C, et al. Five years of successful inducible transgene expression following locoregional adeno-associated virus delivery in nonhuman primates with no detectable immunity. Hum Gene Ther. (2019) 30:802-13. doi: 10.1089/hum.2018.234

54. Sehara Y, Fujimoto KI, Ikeguchi K, Katakai Y, Ono F, Takino N, et al. Persistent expression of dopamine-synthesizing enzymes 15 years after gene transfer in a primate model of parkinson's disease. Hum Gene Ther Clin Dev. (2017) 28:74-9. doi: 10.1089/humc.2017.010

55. Hordeaux J, Hinderer C, Buza EL, Louboutin JP, Jahan T, Bell P, et al. Safe and sustained expression of human iduronidase after intrathecal administration of adeno-associated virus serotype 9 in infant rhesus monkeys. Hum Gene Ther. (2019) 30:957-66. doi: 10.1089/hum.2019.012

56. Mueller C, Gernoux G, Gruntman AM, Borel F, Reeves EP, Calcedo $\mathrm{R}$, et al. 5 Year expression and neutrophil defect repair after gene therapy in alpha-1 antitrypsin deficiency. Mol Ther. (2017) 25:138794. doi: 10.1016/j.ymthe.2017.03.029

57. Wang Z, Storb R, Halbert CL, Banks GB, Butts TM, Finn EE, et al. Successful regional delivery and long-term expression of a dystrophin gene in canine muscular dystrophy: a preclinical model for human therapies. Mol Ther. (2012) 20:1501-7. doi: 10.1038/mt.2012.111

58. Le Guiner C, Servais L, Montus M, Larcher T, Fraysse B, Moullec $\mathrm{S}$, et al. Long-term microdystrophin gene therapy is effective in a canine model of Duchenne muscular dystrophy. Nat Commun. (2017) 8:16105. doi: $10.1038 /$ ncomms 16105

59. Buchlis G, Podsakoff GM, Radu A, Hawk SM, Flake AW, Mingozzi F, et al. Factor IX expression in skeletal muscle of a severe hemophilia B patient 10 years after AAV-mediated gene transfer. Blood. (2012) 119:303841. doi: 10.1182/blood-2011-09-382317

60. Nguyen GN, Everett JK, Raymond H, Kafle S, Merricks EP, Kazazian HH. Long-Term AAV-Mediated Factor VIII Expression in Nine Hemophilia A Dogs: A 10 Year Follow-up Analysis on Durability, Safety and Vector Integration In 61st American Society of Hematology Annual Meeting and Exposition. Orlando, FL (2019) 134:611. doi: 10.1182/blood-2019-126007

61. Niemeyer GP, Herzog RW, Mount J, Arruda VR, Tillson DM, Hathcock J, et al. Long-term correction of inhibitor-prone hemophilia B dogs treated with liver-directed AAV2-mediated factor IX gene therapy. Blood. (2009) 113:797-806. doi: 10.1182/blood-2008-10-181479

62. Finn JD, Ozelo MC, Sabatino DE, Franck HW, Merricks EP, Crudele JM, et al. Eradication of neutralizing antibodies to factor VIII in canine hemophilia A after liver gene therapy. Blood. (2010) 116:58428. doi: 10.1182/blood-2010-06-288001

63. Sabatino DE, Lange AM, Altynova ES, Sarkar R, Zhou S, Merricks EP, et al. Efficacy and safety of long-term prophylaxis in severe hemophilia A dogs following liver gene therapy using AAV vectors. Mol Ther. (2011) 19:4429. doi: $10.1038 / \mathrm{mt} .2010 .240$

64. Crudele JM, Finn JD, Siner JI, Martin NB, Niemeyer GP, Zhou S, et al. AAV liver expression of FIX-padua prevents and eradicates FIX inhibitor without increasing thrombogenicity in hemophilia B dogs and mice. Blood. (2015) 125:1553-61. doi: 10.1182/blood-2014-07-588194

65. Callan MB, Haskins ME, Wang P, Zhou S, High KA, Arruda VR. Successful phenotype improvement following gene therapy for severe hemophilia A in privately owned dogs. PLoS ONE. (2016) 11:e0151800. doi: 10.1371/journal.pone.0151800

66. George LA, Sullivan SK, Giermasz A, Rasko JEJ, Samelson-Jones BJ, Ducore J, et al. Hemophilia B gene therapy with a high-specific-activity factor IX variant. N Engl J Med. (2017) 377:2215-27. doi: 10.1056/NEJMoa1708538

67. Rangarajan S, Walsh L, Lester W, Perry D, Madan B, Laffan M, et al. AAV5factor VIII gene transfer in severe hemophilia A. N Engl J Med. (2017) 377:2519-30. doi: 10.1056/NEJMoa1708483

68. Batty P, Lillicrap D. Advances and challenges for hemophilia gene therapy. Hum Mol Genet. (2019) 28:R95-101. doi: 10.1093/hmg/ddz157

69. Cao O, Hoffman BE, Moghimi B, Nayak S, Cooper M, Zhou S, et al. Impact of the underlying mutation and the route of vector administration on immune responses to factor IX in gene therapy for hemophilia B. Mol Ther. (2009) 17:1733-42. doi: 10.1038/mt.2009.159

70. Mitchell AM, Nicolson SC, Warischalk JK, Samulski RJ. AAV's anatomy: roadmap for optimizing vectors for translational success. Curr Gene Ther. (2010) 10:319-40. doi: 10.2174/156652310793180706

71. Mays LE, Wilson JM. The complex and evolving story of $\mathrm{T}$ cell activation to AAV vector-encoded transgene products. Mol Ther. (2011) 19:1627. doi: $10.1038 / \mathrm{mt} .2010 .250$

72. Wang D, Zhong L, Nahid MA, Gao G. The potential of adeno-associated viral vectors for gene delivery to muscle tissue. Expert Opin Drug Deliv. (2014) 11:345-64. doi: 10.1517/17425247.2014.871258 
73. Boisgerault F, Mingozzi F. The skeletal muscle environment and its role in immunity and tolerance to AAV vector-mediated gene transfer. Curr Gene Ther. (2015) 15:381-94. doi: 10.2174/1566523215666150630121750

74. Kattenhorn LM, Tipper CH, Stoica L, Geraghty DS, Wright TL, Clark KR, et al. Adeno-associated virus gene therapy for liver disease. Hum Gene Ther. (2016) 27:947-61. doi: 10.1089/hum.2016.160

75. Bartolo L, Li Chung Tong S, Chappert P, Urbain D, Collaud F, Colella P. Dual muscle-liver transduction imposes immune tolerance for muscle transgene engraftment despite preexisting immunity. JCI Insight. (2019) 4:127008. doi: $10.1172 /$ jci.insight. 127008

76. Fuchs SP, Martinez-Navio JM, Rakasz EG, Gao G, Desrosiers RC. Liverdirected but not muscle-directed AAV-antibody gene transfer limits humoral immune responses in rhesus monkeys. Mol Ther Methods Clin Dev. (2019) 16:94-102. doi: 10.1016/j.omtm.2019.11.010

77. Haigwood NL, Hessell AJ. Antibodies tip the balance towards an HIV cure. Trends Immunol. (2019) 40:375-7. doi: 10.1016/j.it.2019.03.008

78. Liberatore RA, Ho DD. The miami monkey: a sunny alternative to the berlin patient. Immunity. (2019) 50:537-9. doi: 10.1016/j.immuni.2019. 02.010
79. Caskey M. Delivery of anti-HIV bNAbs by viral vectors. Lancet HIV. (2019) 6:e207-8. doi: 10.1016/S2352-3018(19)30041-4

Disclaimer: The content of this publication does not necessarily reflect the views or policies of the Department of Health and Human Services, nor does mention of trade names, commercial products, or organizations imply endorsement by the U.S. Government.

Conflict of Interest: The authors declare that the research was conducted in the absence of any commercial or financial relationships that could be construed as a potential conflict of interest.

Copyright (c) 2020 Martinez-Navio, Fuchs, Mendes, Rakasz, Gao, Lifson and Desrosiers. This is an open-access article distributed under the terms of the Creative Commons Attribution License (CC BY). The use, distribution or reproduction in other forums is permitted, provided the original author(s) and the copyright owner(s) are credited and that the original publication in this journal is cited, in accordance with accepted academic practice. No use, distribution or reproduction is permitted which does not comply with these terms. 